\title{
ISOLATED AND COMBINED EFFECT OF LEAD NANOPARTICLES AND LEAD ACETAIE WITH SODIUM AND POTASSIUM STEARATES AT PERORAL INTAKE INTO ORGANISM
}

\author{
Kondratiuk V.A., Fedoriv O.Ye., Lototska O.V.
}

\section{І30ЛЬОВАНА I КОМБІНОВАНА ДІЯ НАНОЧАСТИНОК ТА АЦЕТАТУ СВИНЦЮ Э СТЕАРАТАМИ НАТРІІО І КАЛНО ЗА ПЕРОРАЛЬНОГО НАДХОДЖЕННЯ ДО ОРГАНЫЗМУ}

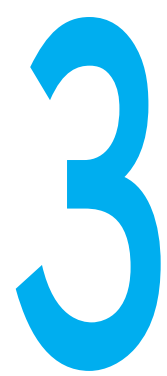

КОНДРАТЮК В.А., ФЕДОРІВ О.є., ЛОТОЦЬКА О.В.

ДВНЗ ,Тернопільський державний медичний університет

ім. І.Я. Горбачевського МОЗ України"

УДК 613.32-099:546.32/ 33-06 : 612.06]-092.9

Ключові слова: наночастинки свинцю, ацетат свинцю, стеарат натрію, стеарат калію, ізольована дія, комбінована дія. абруднення довкілля постійно зростає і посилює негативний вплив на здоров'я людини. 3 забрудненням біосфери пов'язано понад $50 \%$ усіх випадків захворювань, порушень фізичного розвитку та випадків смертей серед населення [1]. Значну групу токсикантів утворюють важкі метали (ВМ) та їхні сполуки, зокрема свинець, який через повітря, воду, продукти харчування потрапляє до організму людини [2-4].

Природними джерелами надходження свинцю у поверхнев води є процеси розчинення деяких мінералів (галенітанглезит, церусит та ін.). Значне зростання вмісту свинцю у навколишньому середовищі (у т.ч. і у поверхневих водах) пов'язане зі спалюванням вугілля, застосуванням тетраетилсвинцю як антидетонатора у моторному паливі, 3 виносом у водні об'єкти зі стічними водами рудозбагачувальних фабрик деяких металургійних заводів, хімічних виробництв, шахт і т.д. [5]. Об'єм сучасного виробництва свинцю становить понад 2,5 млн. т. на рік. У результаті виробничої діяльності у природні води щорічно потрапляє 500-600 тис. т спо- лук свинцю, а майже 400 тис. т осідає на поверхню ґрунту. За даними літературних джерел, вміст свинцю у зонах розміщення підприємств з переробки відпрацьованих та виготовлення свинцевих акумуляторів фонові концентрації свинцю перевищують ГДК у повітрі більше ніж в 1,3 рази, у річках - у 2,0 рази, у ґрунтах - у 4-10 разів [6]. Аналіз динаміки даних гігієнічного моніторингу протягом 1999-2004 років свідчить про поступове зменшення вмісту свинцю в атмосферному повітрі у 7 разів при суттєвому його підвищенні у питній воді та продуктах харчування в 1,3-2,5 рази [7].

Свинець в організмі людини чи тварин здатний стимулювати процеси генерації вільних радикалів, що супроводжуються активацією вільнорадикальних процесів, водночас знижуючи їх нейтралізацію антиоксидантною системою, що призводить до розвитку оксидативного стресу $[8,9]$.

До поширених і небезпечних забруднювачів довкілля належать i різного роду детергенти, у т.ч. стеарати. Значна кількість ПАР потрапляє у відкриті водойми та у води, які згодом використовують-
ИЗОЛИРОВАННОЕ И КОМБИНИРОВАННОЕ ВЛИЯНИЕ НАНОЧАСТИЦ И АЦЕТАТА СВИНЦА СО СТЕАРАТАМИ НАТРИЯ И КАЛИЯ ПРИ ПЕРОРАЛЬНОМ ПОСТУПЛЕНИИ В ОРГАНИЗМ Кондратюк В.А., Федорив О.Е., Лотоцкая Е.В. ГВУЗ „Тернопольский государственный медицинский университет им. И.Я. Горбачевского" Минздрава Украины

Цель работы - изучение характера изолированного и комбинированного действия наночастиц и ацетата свинца со стеаратами натрия и калия при поступлениь их в организм с питьевой водой. Материалы и методы исследования: гигиенические, токсикологические, биохимические, морфологические, гематологические и статистические (Стьюдента, Манна-Уитни), корреляционный анализ, дивизивный и аддитивный варианты расчета коэффициента совместного действия по показателям центральной тенденции, вариабельности и оценок вероятности по М.Ю. Антомонову).

Результаты. Установлено, что в условиях острого санитарно-токсикологического эксперимента ЛД 50 ацетат свинца и наночастицы свинца проявляют одинаковую токсичность, находятся на уровне 294,0 (242,0 :346,0) мг/кг (1 класс токсичности) и обладают выраженной способ- ностью к кумуляции (ИК = 0,7).

Было установлено, что максимально недействующая концентрация равна 0,006 мг/дм³ , с поправкой на класс токсичности - 0,0006 мг/дм³. Ориентировочно безопасный уровень стеарата калия - 0,25 мг/дм³ ${ }^{3}$ стеарата натрия - 0,16 мг/дм ${ }^{3}$ по общесанитарному признаку вредности при контроле качества воды для хозяйственнопитьевого и культурно-бытового назначения. Комбинированное действие наночастиц и ацетата свинца при пероральном употреблении питьевой воды со стеаратами натрия и калия приводит к лейкоцитозу, ускоренному созреванию клеток миелобластного ряда в костном мозге крыс и задержанию их выхода в периферическую кровь из-за неэффективного деления клеток, выраженным сосудистым расстройствам в печени, дистрофическим, некробиотическим изменениям гепатоцитов, соединительнотканных элементов, клеточной инфильтрации стромы. Менее выраженные изменения в структуре исследуемого органа оказывались при комбинированном действии ацетата свинца со стеаратом натрия.

Ключевые слова: наночастицы свинца, ацетат свинца, стеарат натрия, стеарат калия, комбинированное действие, изолированное действие.

() Кондратюк В.А., Федорів О.Є., Лотоцька О.В. СТАТТЯ, 2016. 
ся для водопостачання населення $[10,11]$. Тому вивчення можливої несприятливої дії ПАР на організм теплокровних тварин, особливо у комбінації з BM, наприклад свинцем у нано- і макророзмірах, є актуальною проблемою сьогодення [12].

Метою наших досліджень стало вивчення характеру ізольованої та комбінованої дії наночастинок і ацетату свинцю зі стеаратами натрію та калію за умов перорального надходження їх до організму з питною водою.

Матеріали і методи досліджень. Для досягнення поставленої мети використовували гігієнічні, токсикологічні, біохімічні, морфологічні та гематологічні методи досліджень. Для оцінки достовірності одержаних результатів досліджень використовувалися статистичні методи параметричних та непараметричних критеріїв (Ст'юдента, Манна-Уїтні), кореляційний аналіз, дивізивний та аддитивний розрахунки коефіцієнта сумісної дії за показниками центральної тенденції, варіабельності та оцінок вірогідності [13].

Визначення недіючої концентрації ацетату свинцю проводили на 7 групах білих безпородних щурів по 7 особин у кожній. 1 група була контрольною, в інших групах тваринам вводили ацетат свинцю: 2 гр. - у дозі 70 мг/кг маси тіла, 3 гр. - 3 мг/кг, 4 гр. 0,3 мг/кг, 5 гр. - 0,03 мг/кг, 6 гр. - 0,003 мг/кг, 7 гр. - 0,0003 мг/кг ацетату свинцю. В експерименті використовували ацетат свинцю виробництва ООО „Реактив”, м. Донецьк.

Вивчення санітарно-токсикологічних властивостей стеаратів калію і натрію проводили в умовах гострого експерименту прискореним методом [14]. Тваринам вводили у шлунок стеарат калію і стеарат натрію у дозах 840 мг/кг, 890 мг/кг і 944 мг/кг. Для вивчення токсиколого-гігієнічних властивостей НЧ свинцю та ацетату свинцю щурам вводили у шлунок НЧ свинцю та ацетату свинцю у дозах 200 мг/кг, 250 мг/кг, 282 мг/кг. Динаміку загибелі щурів спостерігали протягом 14 діб.

Для дослідження дії різних форм свинцю ізольовано та у комбінації зі стеаратами натрію і калію в умовах підгострого санітарно-токсикологічного експерименту щурів було розподіле- но на 4 групи по 14 особин: 1 група була контрольною і споживала лише дехлоровану воду з міського водогону, яка за хімічним складом належить до гідрокарбонатно-кальцієвого класу і відповідає вимогам ДержСанПіну України № 2.2.4171-10. Тварини 2, 3 та 4 груп також споживали дехлоровану воду із міського водогону, але тварини 3 гр. - 3 домішками стеарату натрію, а 4 гр. - стеарату калію у дозі 1/250 лД 50 . На 30-й день споживання вказаних вод щурів поділили на дві підгрупи. У першій тваринам 2, 3 та 4 груп перорально вводили НЧ свинцю у дозі 70 мг/кг маси тіла (у дозі 1/110 ЛД 50 ) відповідно, у 2 гр. - ацетат свинцю у дозі 70 мг/кг від маси тіла (у дозі 1/110 ЛД 50$)$. Наночастинки свинцю, які використовувалися в експерименті, були виготовлені ТОВ „Наноматеріали і нанотехноло"іiї" способом газофазного синтезу шляхом випаровування металу за контрольованої температури в атмосфері інертного газу і низького тиску з подальшою конденсацією пари. Згідно з сертифікатом якості наночастинки мали вигляд однорідної прозорої рідини світлого кольору, без запаху, рH розчину 2,5-7,2 одиниць, розмір частинок - 20-70 нм, концентрація свинцю - 1500,00 мг/дм ${ }^{3}$, густина розчину - 1,00015

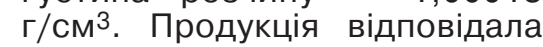
вимогам ту у 24.6-35291116001:2007.

За три доби після проведених досліджень тварин виводили із експерименту шляхом кровопускання під тіопенталовим наркозом з дотриманням правил біоетики. Для оцінки процесів перекисного окиснення ліпідів (ПОЛ) та стану антиоксидантного захисту (АОЗ) визначали активність малонового диальдегіду (МДА), дієнових кон'югатів (ДК), каталази (КАТ), супероксиддисмутази (СОД), церулоплазміну (ЦП) та пероксидазної активності крови (ПАК), показники трансферазної активності - аланінамінотрансферази (АлАТ), аспартатамінотрансферази (АсAТ) у гомогенатах печінки, циркулюючі імунні комплекси (ЦІК) та еритроцитарний індекс інтоксикації (EII) у сироватці крови. Стан периферичної крови та кісткового мозку піддослідних тварин вивчали методом визначення лейкоцитарної формули та складання мієлограми.
Результати та їх обговорення. При вивченні токсичності ацетату та НЧ свинцю в умовах гострого досліду за 10-15 хвилин після введення у шлунок їхнього водного розчину у дозах з розрахунку на свинець 1 групі - 200,0 мг/Кг, 2 - 250,0 мг/Кг, 3 - 282,0 мг/кг у тварин спостерігалися однакові симптоми: збудження (тривожність, почісування мордочки). За 20-30 хв. після затравки розвивалася м'язова слабкість, адинамія, щури збивалися у куток клітки, на подразник майже не реагували, з'являлися ядуха, ціаноз носа, лапок, дискоординація рухів. Потім дихання ставало рідшим, наростав ціаноз видимих слизових оболонок, лапок, конвульсивні судоми і наставала смерть.

Далі за таблицею „лД 50 і їхні довірчі межі" (Пастушенко Т.В. та співавт., 1985) знайшли, що величина LD50 та її довірчі межі для ацетату свинцю і для його Н4 становить 294,0 (242,0 4 $346,0)$ мг/кг. Індекс кумуляції (Ік) і ацетату свинцю, і його НЧ дорівнює 0,7, відповідно речовини мають сильні кумулятивні властивості і належать до 1 класу токсичності.

Для оцінки впливу на організм піддослідних тварин ізольованої та комбінованої дії наночастинок і ацетату свинцю зі стеаратами натрію та калію проводили підгострий експеримент з вивченням показників ПОЛ та АОЗ. Було встановлено, що зі зменшенням дози свинцю ефект був менш вираженим порівняно 3 контрольною групою. Так, у тварин 2 групи при споживанні питної води з наступним пероральним введенням ацетату свинцю у дозі 70 мг/кг вміст МДА у сироватці збільшився у 5,0 разів порівняно з контрольними тваринами $(p<0,001)$. При введенні тваринам 3 мг/кг ацетату свинцю рівень МДА у сироватці крови збільшився в 1,8 рази $(p<0,001), 0,3 \mathrm{мг/кг} \mathrm{-} \mathrm{в} 1,6$ рази $(p<0,001)$ порівняно 3 контрольною групою. При дозі свинцю 0,003 мг/Кг свинцю вміст МДА дорівнював практично контролю. Також в усіх піддослідних групах тварин відбувалося достовірне $(p<0,001)$ збільшення рівня МДА у гомогенаті печінки відносно контролю: у 2 групі - у 3,2 рази, у $3-$ у 2,9, у $4-y$ 2,3 , у 5 - в 1,7 рази. У щурів 6 та 7 груп рівень МДА у печінці був таким, як і в інтактних тва- 
ISOLATED AND COMBINED EFFECT OF LEAD NANOPARTICLES AND LEAD ACETATE WITH SODIUM AND POTASSIUM STEARATES AT PERORAL INTAKE INTO ORGANISM

Kondratiuk V.A., Fedoriv O. Ye., Lototska O.V. SHEI "Ternopil State I.Ya. Horbachevskyi Medical University of the Ministry of Public Health of Ukraine" Objective. We studied a character of isolated and combined effect of lead nanoparticles and lead acetate with sodium and potassium stearates under conditions of their intake with drinking water into organism.

Materials and methods. We used hygienic, toxicological, biochemical, morphological, hematological and statistical methods (Student t-test, Mann-Whitney test), correlation analysis, divisional and additive options for the calculation of the coefficient of joint effect in terms of central tendency, variability and assessments of probability after M.Yu. Antomonov.

Results. Under conditions of acute sanitary-and-toxicological experiment $L D_{50}$ of lead acetate and lead nanoparticles was established to manifest a similar toxicity, to be at the level of 294.0 (242.0 $\div 346.0$ ) $\mathrm{mg} / \mathrm{kg}$ (toxi- city grade 1) and to have a pronounced capacity for cumulation $(\mathrm{Cl}=0.7)$. Maximum non-affecting concentration was ascertained to be equal to $0.006 \mathrm{mg} / \mathrm{dm}^{3}$, adjusted for the grade of toxicity $-0.0006 \mathrm{mg} / \mathrm{dm}^{3}$. A tentatively safe level for potassium stearate is 0.25 $\mathrm{mg} / \mathrm{dm}^{3}$, for sodium stearate $-0.16 \mathrm{mg} / \mathrm{dm}^{3}$ on the basis of general sanitary hazard sign at the control of water quality for domestic-drinking and cultural-and-residential use.

The combined effect of nanoparticles and lead acetate at the peroral use of drinking water with sodium and potassium stearates causes leukocytosis, accelerated maturation of myeloid series of cells in a bone marrow of rats and arrest of their release into peripheral blood due to inefficient cell division pronounced vascular disorders in liver, dystrophic, necrobiotic changes of hepatocytes, connective tissue cells, stromal cell infiltration. Less pronounced changes in the test body structure took place at the combined effect of lead acetate with sodium stearate.

Keywords: lead nanoparticles, lead acetate, sodium stearate, potassium stearate, combined effect, isolated effect. рин. У всіх піддослідних групах тварин відбувалося збільшення рівня МДА у гомогенаті нирок відносно контролю у 2,8 рази (у 2 гр.) та в 1,4 рази (у 3 гр.) $(\mathrm{p}<0,001)$.

При пероральному введенні різних доз свинцю спостерігалося зростання показників АОЗ у сироватці крови. Так, у тварин 3 групи, яким ввели ацетат свинцю у дозі 3 мг/кг, активність КАТ у сироватці крови на $43 \%$ перевищувала даний показник в інтактних щурів. У 4, 5 та 6 груп активність КАТ на $37 \%, 13 \%$ та 8\% відповідно була більшою, ніж у контрольних щурів. Активність КАТ у гомогенаті печінки щурів 2 групи на $150 \%$ перевищувала аналогічний показник інтактних тварин, в усіх інших піддослідних групах лише на кілька відсотків був більшим від контролю. Активність КАТ зросла у гомогенаті нирок тварин 2 групи на 44\%, 3 - на 36\%, 4 - на 22\%, 5 - на $17 \%$ від контрольних величин. Лише у тварин 6 та 7 груп активність КАТ у сироватці крови і тканинах печінки та нирок перебувала у межах контролю.

При пероральному введенні різних доз свинцю спостерігалося значне збільшення активності СОД. Так, активність у крови щурів 2, 3, 4, 5 та 6 груп СОД перевищувала контрольний показник відповідно на $466 \%, 378 \%, 314 \%, 235 \%$ та $114 \%$ відповідно $(p<0,001)$. у гомогенаті печінки щурів активність СОД у 2 групі на 178\% перевищувала контрольні величини, у 3 - на $50 \%$, у 4 на $25 \%$, у 5 - на $20 \%$. У гомогенаті нирок щурів в усіх експериментальних групах тенденція до підвищення активності СОД була менш вираженою. У щурів 6-ї та 7 груп активність ферменту у сироватці крови, гомогенатах печінки та нирок перебувала у межах контрольної групи.

Вміст ЦП у сироватці крови практично у тварин усіх груп перевищував показник в інтактних твари: у 2 групі - на 69\%, у 3 - на $59 \%$, у 4 - на $49 \%$, у 5 на $36 \%$, у 6 - на 18\%. У щурів, яким вводили 0,0003 мг/кг ацетату свинцю, вміст ЦП перебував у межах контрольної величини.

Аналіз кореляційних зв'язків показав високу пряму залежність рівня МДА у сироватці крови, гомогенатах печінки і нирок і концентрації свинцю. Встановлено також високу кореляцію між концентрацією свинцю та вмістом КАТ і ЦП у гомогенатах печінки і нирок (табл.).

При вивченні та гігієнічній оцінці ізольованої дії НЧ та ацетату свинцю і у комбінації зі стеаратами натрію та калію на організм піддослідних тварин було встановлено, що у 3 групі тварин, які споживали питну воду з наявністю стеарату натрію у дозі 250 мг/дм³ ${ }^{3}$ рівень ДК у сироватці крови був у 5,4 разів вищим від контрольних величин, у щурів 4 групи, які споживали питну воду з наявністю стеарату калію у дозі 250 $\mathrm{мг} /$ дм $^{3}$, - у 5,8 разів $(p<0,001)$.

При дослідженні показників ПОЛ у тканині печінки встановлено, що у тварин 2 та 3 груп вміст ДК був практично однаковим та у 2,7 рази перевищував контрольні величини. У тварин 4 групи вміст ДК у 3,3 рази перевищував такий показник в інтактних тварин. Спостерігалося вірогідне $(p<0,01)$ збільшення концентрації ДК у нирках піддослідних тварин у 2, 3 і 4 групах порівняно 3 контрольною відповідно в 1,3; 1,5 і в 1,4 рази.

Динаміка змін МДА у сироватці крови, печінці і нирках мала подібний характер. Комбінована дія стеарату натрію і НЧ свинцю, стеарату калію і НЧ свинцю за більшістю показників ПОЛ, які досліджувалися, мала характер незалежної дії та потенціювання.

НЧ свинцю ізольовано і у комбінації зі стеаратами натрію та калію викликали підвищення

\section{Таблиця \\ Кореляційні зв'язки між концентрацією свинцю та змінами біохімічних показників у сироватці крови, гомогенатах печінки і нирок у піддослідних тварин}

\begin{tabular}{|l|c|}
\hline \multicolumn{1}{|c|}{ Показник } & Коефіцієнт кореляції \\
\hline МДА крови & $r=0,88^{\star \star}$ \\
\hline МДА печінки & $r=1,00^{\star \star}$ \\
\hline МДА нирок & $r=0,95^{\star \star}$ \\
\hline КАТ крови & $r=-0,44$ \\
\hline КАТ печінки & $r=0,92^{\star \star}$ \\
\hline КАТ нирок & $r=0,97^{\star \star}$ \\
\hline СОД крови & $r=0,24$ \\
\hline СОД печінки & $r=0,02$ \\
\hline СОД нирок & $r=0,50$ \\
\hline ЦП крови & $r=0,75^{\star}$ \\
\hline
\end{tabular}

Примітки:

* - r вірогідний $(P<0,05)$;

** - $r$ вірогідний $(P<0,01)$. 
активності СОД у сироватці крови $(p<0,01)$ : у тварин 2 групи - у 6,5 разів, у 3 гр. - у 6,7 разів, у 4 гр. - у 5,6 разів; у печінці - у тварин 2 групи - в 1,7 рази, у 3 та 4 груп - у 3,5 рази порівняно 3 контролем. Активність СОД у нирках білих щурів у 2 групі зросла у 4,7 рази ( $<<0,05)$. У тварин 3 і 4 груп практично не змінилася.

Активність КАТ у сироватці крови піддослідних тварин статистично достовірно збільшилася: у 2 групі - в 1,5 рази, у 3 -у 2,4 рази, у 4 - у 2,2 рази порівняно 3 контролем. Аналогічні зміни спостерігалися і у тканинах печінки. Так, у 2 групі активність КАТ зросла у 3 рази, у 3 у 2,9 рази, у $4-$ у 2,5 рази $(p<0,01)$. Під впливом води різного складу у поєднанні з Н4 свинцю спостерігалося і підвищення активності КАТ у тканині нирок білих щурів.

Комбінована дія стеаратів натрію і калію та НЧ свинцю за показниками пОЛ і AOC мала характер незалежної дії та потенціювання. Антагоністична дія спостерігалася лише за змінами СОД у нирках.

При пероральному введенні нч свинцю у комбінації зі стеаратами натрію та калію відзначалося зниження активності АлАТ та АсАТ у печінці експериментальних тварин порівняно 3 інтактними у $3,7,3,0$ та 2,7 разів відповідно ( $p<0,001)$.

При надходженні до організму НЧ свинцю підвищувався рівень ЦІК в усіх піддослідних групах в $1,2-2,2$ рази $(p<0,001)$. Результати досліджень показали, що у тварин 2, 3 та 4 груп Ell статистично достовірно $(p<0,001)$ зростав відповідно у 2,1, 2,2 та 1,9 рази порівняно з інтактними тваринами.

Встановлено, що субтоксичні дози стеаратів натрію і калію та НЧ свинцю у комбінації зі стеаратами викликали лейкоцитоз крови у піддослідних тварин. У кістковому мозку також збільшувалася кількість промієлоцитів, паличкоядерних, сегментоядерних нейтрофілів та лімфоцитів.

Проведені морфологічні дослідження печінки при надходженні НЧ свинцю у поєднанні зі стеаратом натрію виявили розлади кровообігу з порушенням часточкової структури печінки, помірною білковою дистрофією гепатоцитів та посиленням макрофагальної активності, некротичними змінами. Вплив НЧ свинцю у поєднанні зі стеа- ратом калію призводив до різкого порушення структури печінки з розвитком дистрофічно-некротичних змін з формуванням мультиглобулярних некрозів.

За комбінованіої дії води зі стеаратом калію та з пероральним введенням 70 мг/кг ацетату свинцю зростав рівень ДК та МДА у сироватці крови порівняно з контрольною групою, особливо у тварин 2 групи. Так, вміст ДК був майже у 4,5 рази вищим, ніж у контрольній групі $(p<0,001)$. У тварин 3 групи рівень ДК був у 5,2 рази, а $4-$ $6,0$ разів вищим ( $p<0,001)$. Рівень даного показника у печінці тварин 2, 3 та 4 груп у 3,5 рази перевищував вміст ДК у тварин контрольної групи ( $<<0,001)$. У нирках білих щурів збільшувався даний показник у 2, 3 та 4 групах порівняно з контролем в $1,6,1,5$ та у 1,9 рази відповідно ( $p<0,001)$. Вміст МДА у сироватці крови зріс майже у 6,0 разів порівняно з контролем $(p<0,001)$, а при споживанні звичайної води (2 гр.) - у 5,0 разів. Динаміка змін МДА у печінці і нирках тварин мала такий саме характер, як і у сироватці крови.

Комбінована дія стеаратів натрію і калію та ацетату свинцю за більшістю показників ПОЛ, які досліджувалися, переважно мала характер незалежної дії. Потенціювання проявлялося лише за зміною вмісту МДА та ДК у сироватці крови та вмісту МДА у нирках.

За комбінованої дії 70 мг/кг ацетату свинцю зі стеаратами натрію і калію зростала активність АОЗ. Активність СОД у 3 групі тварин, які споживали воду з вмістом стеарату натрію, була у 6,2 разів вищою порівняно 3 інтактними тваринами. У щурів 2 групи, що споживали воду без стеаратів, концентрація СОД була у 6,1 разів вищою $(p<0,001)$, ніж у контрольних тварин, а у тварин 4 групи - у 5,5 разів $(p<0,001)$.

За комбінованої дії води зі стеаратами з подальшим пероральним введенням ацетату свинцю відбувалося статистично достовірне зростання активності СОД у печінці. Так, в експериментальних тварин 3 і 4 груп, що споживали воду зі стеаратами натрію та калію, активність СОД у 6,3 та 8,4 разів $(p<0,001)$ перевищувала активність даного ферменту у тварин контрольної групи. У тварин 2 групи активність СОД була у 4,3 рази вищою. Також зростала активність КАТ у сироватці крови, печінці і нирках піддослідних тварин, збільшувалася ПАК крови та концентрація цП.

За зміною більшості показників AOC спостерігався незалежний тип комбінованої дії. Комбінована дія стеарату натрію та ацетату свинцю за вмістом СОД в органах-мішенях печінці та нирках і ЦП у сироватці крови відбувалася за типом потенціювання. За комбінованої дії стеаратів натрію і калію та ацетату свинцю спостерігалося зниження активності АлАТ та АсАТ у печінці порівняно 3 інтактними тваринами. При введенні до організму ацетату свинцю підвищувався рівень ЦІК, а також збільшувався Ell.

Комбінована дія стеарату натрію та ацетату свинцю, стеарату калію та ацетату свинцю у статевозрілих щурів відбувалася за типом антагонізму за змінами рівня ЦІК. Ацетат свинцю у комбінації зі стеаратами натрію і калію викликав збільшення кількості лейкоцитів у крови та у кістковому мозку тварин.

При морфологічному дослідженні печінки встановили, що у разі перорального надходження з питною водою ацетату свинцю зі стеаратами натрію і калію призводить до виражених судинних розладів у печінці, дистрофічних, некробіотичних змін гепатоцитів, сполучнотканинних елементів, клітинної інфільтрації строми. Менш виражені зміни у структурі досліджуваного органа виявлялися за комбінованої дії ацетату свинцю зі стеаратом натрію.

\section{Висновки}

1. ЛД 50 ацетату свинцю і наночастинки свинцю проявляють однакову токсичність і перебувають на рівні 294,0 (242,0 : $346,0)$ мг/кг (1 клас токсичності) та мають виражену здатність до кумуляції ( $\left.\mathrm{I}_{\mathrm{K}}=0,7\right)$.

2. При введенні свинцю у дозі 0,0003 мг/кг у сироватці крови і гомогенатах печінки та нирок показники пероксидного окиснення ліпідів та антиоксидантної системи перебували у межах контрольних величин, тому дозу свинцю 0,0003 мг/кг можна вважати недіючою. Встановлена максимальнонедіюча концентрація дорівнює 0,006 мг/дм ${ }^{3}, 3$ поправкою на клас токсичності - 0,0006 мг/дм³ ${ }^{3}$. Орієнтовно-безпечний 
рівень стеарату калію - 0,25 мг/дм ${ }^{3}$, стеарату натрію - 0,16 мг/дм³ за загально-санітарною ознакою шкідливості під контролем якості води для господарсько-питного і культурнопобутового використання.

3. За комбінованої дії наночастинок та ацетату свинцю зі стеаратами натрію і калію спостерігався лейкоцитоз, особливо у білих щурів при споживанні води зі стеаратом калію, ніж при споживанні стеарату натрію. У кістковому мозку щурів проявлялося прискорене дозрівання клітин мієлобластного ряду і затримання їх виходу у периферичну кров через неефективний поділ клітин.

4. Комбінована дія наночастинок свинцю та ацетату свинцю при пероральному споживанні питної води зі стеаратом натрію і стеаратом калію призводить до виражених судинних розладів у печінці, дистрофічних, некробіотичних змін гепатоцитів, сполучнотканинних елементів, клітинної інфільтрації строми. Менш виражені зміни у структурі досліджуваного органа виявлялися за комбінованої дії ацетату свинцю зі стеаратом натрію.

ЛІТЕРАТУРА

1. Сердюк А.М. Гігієнічні проблеми України на рубежі століть / А. М. Сердюк // Гігієнічна наука і практика на рубежі століть: матер. XIV з'їзду гігієністів України. - Дніпропетровськ: АРТ-ПРЕС, 2004. - С. 30-33.

2. Биомониторинг в оценке риска развития профессиональных интоксикаций / В.П. Чащин, Г.И. Сидорин, Л.В. Фролова и др. // Медицина труда и промышленная экология. - 2004. - № 12. - C. 10-12.

3. Эльбекьян К.С. Влияние мелатонина на биохимические показатели токсичности солей тяжелых металлов при внутрибрюшинном введении крысам / К.С. Эльбекьян // Токсикологический вестник. - 2006. № 1. - C. 24-26.

4. Возрастные и половые различия в гематологических эффектах при длительном поступлении свинца и марганца из окружающей среды в организм человека / С.Д. Иванов, У.Ю. Нечипоренко, Е.Г. Кованько и др. // Токсикологический вестник. - 2005. - № 3. C. 16-19.

5. Пурмаль А.П. Антропогенная токсикация планеты. Ч. 1 / А.П. Пурмаль // Соросовский образовательный журнал. 1998. - № 9. - С. 39-45.
6. Главацька В.І. Комплексна гігієнічна оцінка регіональних особливостей забруднення об'єктів навколишнього середовища свинцем і його впливу на показники здоров'я дітей : дис. канд. мед. наук : 14.02.01 / Дніпропетровська державна медична академія. - Д., 2006. -202 c.

7. Трахтенберг И.М. Свинец и окислительный стресс / И.М. Трахтенберг,

Т.К. Короленко, Н.А. Утко // Современные проблемы токсикологии. - 2001. - № 4. C. 50-53.

8. Першин О.І. Оксидативний стрес у патогенезі дії ацетату свинцю / О.І. Першин // Світ медицини та біології. - 2014. № 1 (43). - - C. 142-146.

9. Environmental Health Criteria 170. Assessing human health risks of chemicals: derivation of guidance values for health-based exposure limits. - Geneva: WHO, 1994. - 73 p.

10. Проданчук М.Г.

Поверхнево-активні речовини: токсиколого-гігієнічні та мікробіологічні аспекти /

М.Г. Проданчук, І.В. Мудрий, А.А. Калашников. - К. : Медицина України, 2006. - 223 с.

11. Jain K.K. Nanomedicine: application of nanobiotechnology inmedicalpractice // Med. Princ. Pract. - 2008. - Vol. 17, № 2. P. 89-101.

12. Фостер Л. Нанотехнологии. Наука, инновации и возможности : пер. с англ. - М. : Техносфера, 2008. - 350 c.

13. Антомонов М.Ю. Математическая обработка и анализ медико-биологических данных / М.Ю. Антомонов. - К., 2006. 558c.

14. Экспресс-метод определения среднесмертельных доз химических веществ / Т.В. Пастушенко, Л.Б. Маруший, А.А. Жуков, Ю.А. Пилипенко // Гигиена и санитария. - 1985. № 6. - C. 46-48.

REFERENCES

1. Serdiuk A.M. Hihiienichni problemy Ukrainy na rubezhi stolit [Hygienic Problems of Ukraine at the Turn of the Centuries]. In : Hihiienichna nauka i praktyka na rubezhi stolit: materialy XIY zizdu hihiienistiv Ukrainy [Hygienic Science and Practice at the Turn of the Centuries: Materials of XIV Congress of the Hygienists of Ukraine]. Dnipropetrovsk : ARTPRES ; 2004 : 30-33 (in

Ukrainian).

2. Chashchin V.P.,

Skhodkina N.I., Frolova A.D.,
Lukovnikova L.V., Sidorin G.I. Meditsina truda i promyshlennaia ekologiia. 2004 ; 12 : 10-12 (in Russian).

3. Elbekian K.S. Toksikologicheskii vestnik. 2006 ; 1 : 2426 (in Russian).

4. IvanovS.D., Nechyporenko U.Yu., Kovanko E.G., Yamshanov V.A., Ivanova A.S., Ivanova T.M., Semenov E.B., Petrov A.N. Toksikologicheskii vestnik. 2005 ; 3: 16-19 (in Russian).

5. Purmal A.P. Sorosovskii obrazovatelnyi zhurnal. $1998 ; 9$ : 3945 (in Russian).

6. Hlavatska V.I. Kompleksna hihiienichna otsinka rehionalnykh osoblyvostei zabrudnennia obiektiv navkolyshnoho seredovyshcha svyntsem i yoho vplyvu na pokaznyky zdorovia ditei : dys. kand. med. nauk [Complex Hygienic Assessment of the Regional Features of the Environmental Contamination with Lead and its Effect on the Indices of Children's Health : Med. Sci. Cand. Thesis].

Dnipropetrovsk ; 2006 : 202 p. (in Ukrainian).

7. Trakhtenberg I.M., Korolenko T.K.. Utko N.A. Sovremennye problem toksikologii. 2001 ; 4 : 50-53 (in Russian).

8. Pershyn O.I. Svit medytsyny ta biolohii. 2014. № 1 (43) (in Ukrainian).

9. IPCS Environmental Health Criteria 170. Assessing Human Health Risks of Chemicals: Derivation of Guidance Values for Health-Based Exposure Limits. Geneva: WHO ; 1994 : 73 p.

10. Prodanchuk M.H.,

Mudryi I.V.. Kalashnikov A.A.

Poverkhnevo-aktyvni rechovyny: toksykoloho-hihiienichni ta mikrobiolohichni aspekty [Surfactants: Toxicological-Hygienic and Microbiological Aspects]. Kyiv : Medytsyna Ukrainy ; 2006 : 223 p. (in Ukrainian).

11. Jain K.K. Med. Princ. Pract. 2008 ; 17 (2) : 89-101.

12. Foster L. Nanotekhnologii. Nauka, innovatsii i vozmozhnosti [Nanotechnologies. Science, Innovations and Possibilities]. Moscow : Tekhnosfera ; 2008 : 350 p. (in Russian).

13. Antomonov M.Yu.

Matematicheskaia obrabotka i analiz mediko-biologicheskikh dannykh [Mathematical Processing and Analysis of Medico-Biological Data]. Kiev ; 2006 : 558 p. (in Russian).

16. Pastushenko T.V., Marushii L.B., Zhukov A.A. PilipenkoYu.A. Gigiena i sanitariia. 1985 ; $6: 46-48$ (in Russian). Надійшла до редакції 10.01.2016 